\title{
EROSIVE POTENTIAL OF SPORTS BEVERAGES ON HUMAN ENAMEL “IN VITRO”
}

\author{
POTENCIAL EROSIVO DE BEBIDAS ESPORTIVAS NO ESMALTE HUMANO "IN VITRO"
}

Original Article Artigo Original POTENCIAL EROSIVO DE BEBIDAS DEPORTIVAS EN EL ESMALTE HUMANO "IN VITRO" Artículo Original

\author{
Dalila Meazza Damo' \\ (Dentist) \\ Guilherme Anziliero Arossi ${ }^{2}$ \\ (Dentist) \\ Helena Alvez da Silva' \\ (Dentist) \\ Leonardo Haerter dos Santos 3 \\ (Mechanical Engineer) \\ Diego Rafael Kappaun ${ }^{2}$ \\ (Chemical Engineer)
}

1. Universidade Luterana do Brasil (ULBRA), Torres, RS, Brazil.

2. Universidade Luterana do Brasil (ULBRA), Post Graduation Program in Health Promotion, Human Development and Society, Canoas, RS, Brazil.

3. Universidade Luterana do Brasil (ULBRA), Department of Mechanical Engineering, Canoas, RS, Brazil.

\section{Correspondence:}

Guilherme Anziliero Arossi Universidade Luterana do Brasil. Av. Farroupilha, 8001, Bairro São José, Canoas, RS, Brazil. 92425-900. guilhermeclinica@gmail.com

\begin{abstract}
Introduction: The low pH of sports drinks may cause tooth enamel demineralization. Objective:To measure Vickers hardness of human enamel exposed to sports drinks. Methods: Human molars were used to collect the enamel samples. Each sample had a test surface (exposed to the drinks) and a control surface (unexposed). The samples were exposed to isotonic drinks Gatorade and Powerade, and to maltodextrin drinks Malto Advanced and Malto Active, for 10 minutes every 12 hours over 30 days. The Vickers microhardness test was conducted with three indentations on each surface. The mean of the indentations within each group was considered in the statistical analysis. Sports drinks variables were analyzed with ANOVA/Tukey $(p \leq 0.01)$. The independent t-test was used in the comparison between the control and test surfaces of each drink ( $p \leq 0.05$ ). Results: Enamel exposure to Gatorade $(p=0.000)$ Malto Advanced $(p=0.000)$ and Malto Active $(p=0.000)$ was seen to significantly reduce microhardness, while the isotonic drink Powerade had no significant effect on enamel $(p=0.248)$. Conclusion: It was concluded that with the exception of the isotonic drink Powerade, all the sports drinks tested caused a reduction in the microhardness of human enamel. Evidence Level III; Therapeutic studies Investigating the Results of Treatment.
\end{abstract}

Keywords: Energy drinks; Tooth demineralization; Tooth erosion; Dental enamel.

\section{RESUMO}

Introdução: O baixo pH de bebidas esportivas pode promover perda mineral do esmalte dental. Objetivo: Avaliar a microdureza Vickers do esmalte humano exposto a bebidas esportivas. Métodos: Dentes molares humanos foram usados para coletar as amostras de esmalte. Cada amostra apresentou uma superfície de teste (exposta às bebidas) e uma superfície de controle (não exposta). As amostras foram expostas aos isotônicos Gatorade e Powerade e às maltodextrinas Advanced Series e Malto Active durante 10 minutos de 12/12 horas, durante 30 dias. O teste de microdureza Vickers foi realizado com três indentações em cada superfície. Na análise estatística, foi considerada a média das indentações dentro de cada grupo. As variáveis bebidas esportivas foram avaliadas com ANOVAATukey $(p \leq 0,01)$. Na comparação entre a superficie controle e teste de cada bebida foi utilizado o Teste t para amostras independentes $(p \leq 0,05)$. Resultado: Observou-se que a exposição do esmalte a Gatorade $(p=0,000)$, Malto Advanced $(p=0,000)$ e Malto Active $(p=0,000)$ reduz significativamente a microdureza, enquanto que o isotônico Powerade não produziu efeito significativo sobre o esmalte $(p=0,248)$. Conclusão: Concluiu-se que com exceção do isotônico Powerade, todas as bebidas esportivas testadas provocaram redução na microdureza do esmalte dental humano. Nivel de Evidência III; Estudos terapêuticos - investiga o resultado de um tratamento.

Descritores: Bebidas energéticas; Desmineralização dentária; Erosão dentária; Esmalte dentário.

\section{RESUMEN}

Introducción: El bajo pH de bebidas deportivas puedefavorecer la pérdida mineral del esmaltedental. Objetivo: Evaluarel esmalte dureza Vickers humano expuesto a las bebidas deportivas. Métodos: Se utilizaron los dientes molares para la toma de las muestras de esmalte. Cada muestra tenía una superficie de prueba (expuestos a las bebidas) y una superficie de control (no expuesta). Las muestras fueron expuestas en isotónica Gatorade y Powerade, y maltodextrinas, y la serie Advanced activo Malto durante 10 minutos 12/12 horas durante 30 días. La prueba de dureza Vickers se realizó con tres muescas en cada superficie. El análisis estadístico fue la media de las muescas dentro de cada grupo. variables de bebidas deportivas se analizaron con ANOVA/Tukey ( $p \leq 0,01$ ). La comparación entre la superficie de controly prueba de cada bebida se utilizóla prueba tpara muestras independientes $(p \leq 0,05)$. Resultados: Seobservóque la exposición del esmalte Gatorade $(p=0,000)$ Malto avanzada $(p=0,000)$ y Malto activo $(p=0,000)$ reduce significativamente la dureza, mientras que Powerade isotónica ningún efecto significativo sobre el esmalte $(p=0,248)$. Conclusión: Se concluye que con la excepción de Powerade isotónica, todas las bebidas deportivas probados causó una reducción en la dureza del esmalte humano. Nivel de Evidencia; Estudios terapéuticos - Investigación de los resultados del tratamento.

Descriptores: Bebidas Energéticas Alcohólicas; Desmineralización Dental; Erosión de los Dientes; Esmalte Dental. 


\section{INTRODUCTION}

Intense physical activity can lead to increased consumption of energy-replenishing drinks by professional or amateur athletes who seek to improve their performance. These drinks are indicated for replenishing an individual's hydroelectrolyte loss after an intense physical exercise. Despite restrictions to their consumption, energy supplements are becoming quite popular due to their low costs, easy accessibility, media influence and are excessively and indiscriminately consumed for ergogenic and esthetic purposes or even for their pleasant taste. ${ }^{1-4}$

According to Ordinance no. 222 of the Ministry of Health, energy-replenishing drinks are formulated with varied concentration of electrolytes and carbohydrates, nutrients that maintain an appropriate level of energy for athletes. . $^{6}$ They are taken during sports activities in order to increase glycemia and keep the organism hydrated. ${ }^{7}$ Nevertheless, consumption of these drinks may present a risk to oral hygiene, causing dental erosion.

Dental erosion is the loss of dental structure by chemical processes without bacterial involvement, through exposure to acidic substances. The acidic attack produces an irreversible loss to hard dental tissue. 5, 8-12 Non-carious loss of dental tissue is a physiological process that occurs throughout life. However, it may be considered pathological when the degree of destruction becomes excessive, causing functional and esthetic problems and/or provoking dental sensitivity. ${ }^{12}$

Loss of normal whiteness, thin or fractured incisal edges, rounding of cuspids, depressions on surfaces, loss of dental morphology, and in more serious cases, dentin exposure are among the clinical characteristics of dental erosion lesions. . $^{8,13-15}$

Erosion may be extrinsic or intrinsic in origin. Extrinsic erosion is caused by acids arising from the external means, such as diet (acidic beverages and foods), chronic consumption of medication/drugs, or the environment. 2,10,11,16,17

Acids of extrinsic origin are considered as the main factors related to the occurrence of dental erosion through consumption of acidic foods and drinks, such as sodas, wines, teas, citric fruits, fruit juices, and sports drinks. ${ }^{1-4,10-12,15,17-20}$

The $\mathrm{pH}$ level of beverages is the factor associated with dental erosion. Any acidic substance with a $\mathrm{pH}$ level below the critical $\mathrm{pH}$ for enamel $(\mathrm{pH}=5.5)$ has the capacity to dissolve hydroxyapatites, causing demineralization, especially if the attack is chronic and long in duration. 1,18,20 However, acid concentration; the type of acid; sugar, calcium, phosphate, carbohydrate, and fluoride content; temperature; the amount of time in the oral cavity; the product's adherence to the dental surface; chelating properties; intake frequency; and buffering capacity are also relevant factors. ${ }^{10,11,16-18}$

In order to identify a drink's capacity to cause dental erosion, the hardness of the dental surface should be measured. Hardness is capable of qualitatively determining the amount of mineral in its composition., 33,18 The Vickers microhardness test is based on the resistance that the material offers against the penetration of a diamond, where the hardness value is the quotient of the load applied over the surface area of the indentation left on the tested body.11,21

Therefore, this study aimed to evaluate the Vickers microhardness of human enamel submersed in different commercially available sports drinks.

\section{METHOD}

The work is part of the project "The Influence of Energy Drinks on the Surface of Human Dental Enamel" approved by the Research Ethics Committee under the protocol number 853.690 .
Eight human molars were selected from the Human Teeth Bank in the Dental School at the Lutheran University of Brazil, Torres campus, which fit the following criteria: intact enamel; no tooth decay; and no restorations, fractures, and/or cracks.

In order to create the sample, molars were sectioned with a diamond disc (KG Sorensen, Cotia, SP, Brazil) in low rotation (Kavo, Joinville, SC, Brazil), under abundant refrigeration, separating the crown and root portions. The crown was sectioned in parallel along the axis to obtain fragments of the vestibular and lingual/palatal dental surfaces. ${ }^{9,19}$ To compensate for dental convexity and obtain flat surfaces, each enamel surface was sectioned in the occlusal-apical direction into four pieces. This way, each tooth provided eight enamel samples, and with eight teeth, 64 samples were gathered. Of these, 40 samples were selected based on visual examination, considering the criteria for inclusion.

The samples were immersed in autopolymerizing acrylic resin (Clássico, Campo Limpo Paulista, SP, Brazil), leaving the enamel surfaces exposed. A carborundum disc (Carborundum, New York, U.S.A.) was used to even out the enamel surface parallel to the exposed surface of the sample. The sample then underwent surface polishing using a polishing paste (FGM, Joinville, SC, Brazil) and Optimize burs (TDV, Pomerode, SC, Brazil) for finishing and polishing set at low rotation. A smooth, regular, and even surface is important in conducting the microhardness analysis. $3,9,19$

Half of the enamel surface of each sample was covered with red nail polish (Risque, Barueri, SP, Brazil) to avoid contact with the test liquid. Therefore, each sample had a test surface that came into contact with sports beverages and a control surface that remained unexposed. ${ }^{17}$ Figure 1 shows the step-by-step process in creating the sample.

Two commercially available brands of hydroelectrolyte-replenishing drinks were chosen: Gatorade (PepsiCo, JA5026, October 2015, Porto Alegre, RS, Brazil) and Powerade (Coca-Cola, S4579, September 2015, Porto Alegre, RS, Brazil), and two brands of energy supplements (maltodextrin): Advanced Series (New Millen Suplementos, 28182, January 2017, Cajamar, SP, Brazil) and Malto Active (DNA Suplementos, 121114 November 2015, Poços de Caldas, MG, Brazil). "Lime flavor" and "room temperature" were standardized. Table 1 presents the composition of the sports drinks, according to the manufacturer.

The isotonic sports beverages were ready for use, but maltodextrin is sold as a powder and must be dissolved in water. Following the powder and water proportions indicated by the manufacturers, $10 \mathrm{~g}$ of maltodextrin was dissolved in $50 \mathrm{~mL}$ of publicly supplied water before each exposure.

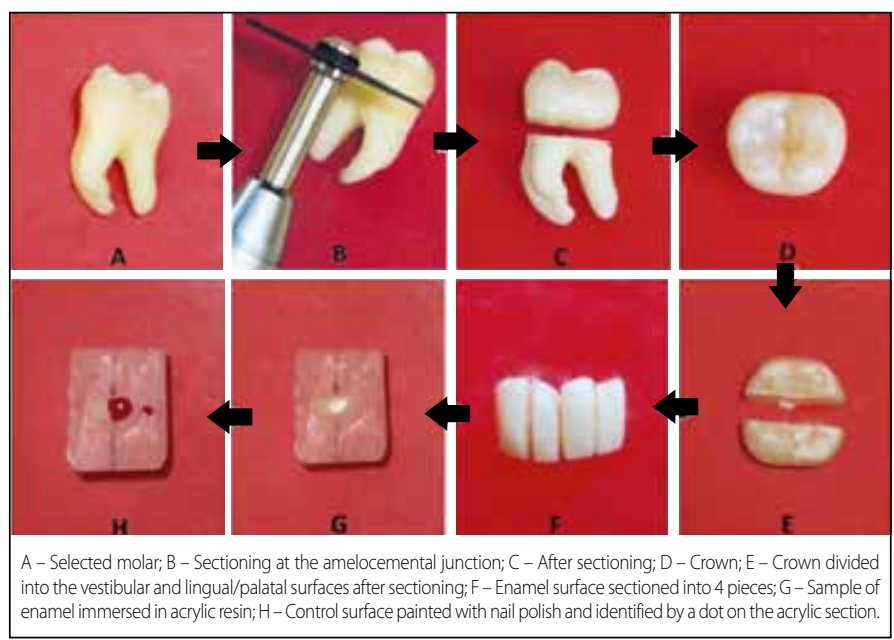

Figure 1. Creating the samples. 
The samples were stored in distilled water (Sealife Farmácia de Manipulação, Torres, RS, Brazil) for $24 \mathrm{~h}$ and then randomly distributed among the four groups, with each group containing 10 samples that represented a drink: Gatorade, Powerade, Malto Advanced, and Malto Active.

For each test, the samples were submersed into $50 \mathrm{~mL}$ of test solution for 10 min and were washed with distilled water in the end. Two daily tests were conducted for 30 consecutive days with 12-h intervals, resulting in $600 \mathrm{~min}(10 \mathrm{~h}$ ) of exposure. During the rest period in between tests, all the samples remained in the distilled water. ${ }^{3,9,19}$

After the exposure to sports drinks, the nail polish was removed from the control surfaces by scraping the surface with the aid of a \#7 spatula (Quinelato, Rio Claro, SP, Brazil). Subsequently, the samples underwent a Vickers microhardness test.

The microhardness tests were performed using a Vickers microhardness tester (INSIZE, São Paulo, Brazil), as shown in Figure 2, with a load of $100 \mathrm{~g}$ for $10 \mathrm{~s}$. Three indentations were made on the surface of each sample, with one in the center and the other two along the superior and inferior ends.

The microhardness data from each measurement were gathered for each group. To homogenize the values obtained, the two highest and lowest values within the same group were eliminated, totaling an average of 20 indentations by surface type within each beverage group $(n=20)$.

Table 1. Sports drink composition, according to manufacturers.

\begin{tabular}{c|c|c}
\hline Brand name & Manufacturer & \multicolumn{1}{c}{ Composition } \\
\hline Gatorade & PepsiCo & $\begin{array}{r}\text { Water, sucrose, glucose, sodium chloride, } \\
\text { sodium citrate, monopotassium phosphate, } \\
\text { citric acid acidulant, artificial flavoring, and } \\
\text { beta-carotene natural coloring. }\end{array}$ \\
\hline Powerade & Coca Cola & $\begin{array}{r}\text { Water; sugar; sodium chloride; potassium } \\
\text { citrate; magnesium chloride; calcium } \\
\text { chloride; potassium phosphate; vitamins } \\
\text { B3, B6 and B12; citric acid acidulant; } \\
\text { artificial flavoring; stabilizers; sucrose } \\
\text { acetate isobutyrate and dioctyl sodium } \\
\text { sulfosuccinate; sucralose sweetener; } \\
\text { tartrazine artificial coloring. }\end{array}$ \\
\hline Maltodextrin & New Millen & $\begin{array}{r}\text { Maltodextrin, dehydrated lime pulp (1\%), } \\
\text { citric acid acidulant, artificial flavoring, and } \\
\text { sucralose sweetener. }\end{array}$ \\
\hline Maltodextrin & DNA & $\begin{array}{r}\text { Maltodextrin, artificial lime flavoring, citric } \\
\text { acid, and yellow coloring. }\end{array}$ \\
\hline
\end{tabular}

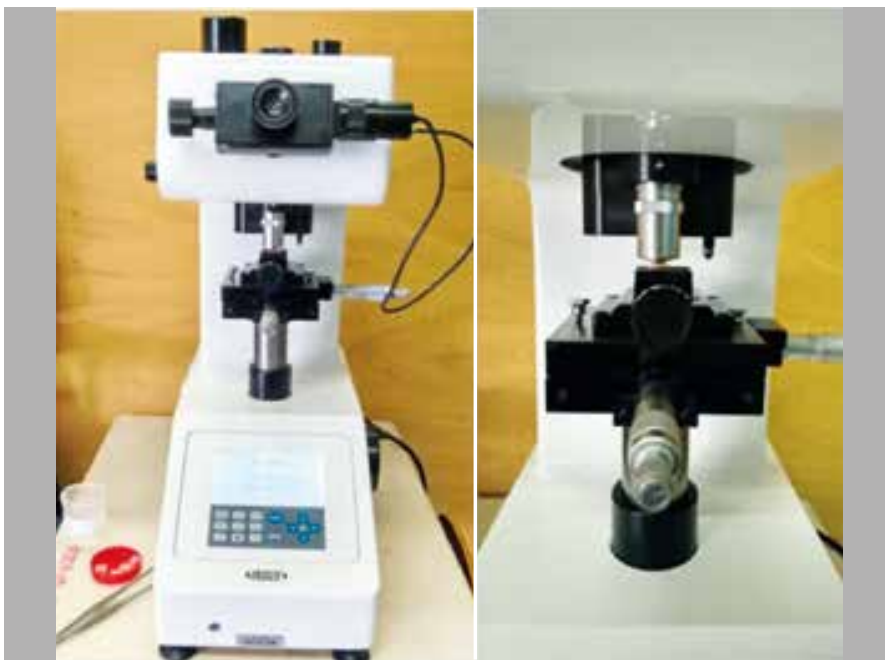

Figure 2. Vickers Microhardness Tester used to perform the test.
SPSS version 17.0 (SPSS Inc., Chicago, IL, U.S.A.) was the software used for statistical analysis. To compare the sports drinks groups, the analysis of variance was used with differentiation among the groups by the Tukey test, considering statistical significance of $p \leq 0.01$. To compare each beverage's control and test surfaces, the independent sample t-test was employed, considering statistical significance of $p \leq 0.05$.

\section{RESULTS}

The mean and standard deviations of Vickers microhardness are presented in Table 2, in addition to the statistically significant results among the test and control surfaces of each drink and among the surfaces exposed to the beverages. Figure 3 depicts the decrease in microhardness of the enamel exposed to the sports drinks.

Exposure to the isotonic sports beverages, i.e., Gatorade, Malto Advanced, and Malto Active, has a statistically significant effect on the microhardness of dental enamel, whereas the isotonic sports drink Powerade, despite causing a decrease in microhardness (8.77), had no statistically significant effect.

The control surfaces for Gatorade, Malto Advanced, and Malto Active presented similar significance in the microhardness of the enamel. When compared with the test surfaces of different sports drinks, all surfaces were observed to have statistically significant results among each other.

In examining the decrease in microhardness of the enamel, maltodextrin, Malto Active and Malto Advanced was observed to have the highest capacity for erosion (164.17 and 154.17) compared to the isotonic sports beverages, Gatorade and Powerade, which demonstrated a smaller decrease in microhardness (68.58 and 8.77).

Table 2. Mean and standard deviations of microhardness of the control and test surfaces based on sports drinks.

\begin{tabular}{c|c|c|c}
\hline Beverages & Control surface & Test surface & $\mathbf{P}^{* * *}$ \\
\hline gatorade & $242.49(30.06)^{\mathrm{B}^{*} \mathrm{a}^{* *}}$ & $173.91(22.38)^{\mathrm{Bb}}$ & 0.000 \\
\hline Powerade & $298.62(25.26)^{\mathrm{Aa}}$ & $289.85(21.97)^{\mathrm{Aa}}$ & 0.248 \\
\hline Malto Advanced & $270.41(35.33)^{\mathrm{ABa}}$ & $116.24(62.90)^{\mathrm{Cb}}$ & 0.000 \\
\hline Malto Active & $240.47(23.17)^{\mathrm{Ba}}$ & $76.30(26.64)^{\mathrm{Db}}$ & 0.000 \\
\hline
\end{tabular}

*Different upper case letters in the same column indicate the statistical difference among the drinks in the ANOVA Tukey test $(p \leq 0.01)$. **Different lower case letters on the same line indicate the statistical difference among the control and test surfaces in the independent sample t-test $(p \leq 0.05)$. *** $p$-value when we compared the control surface with the test surface using the independent sample t-test.

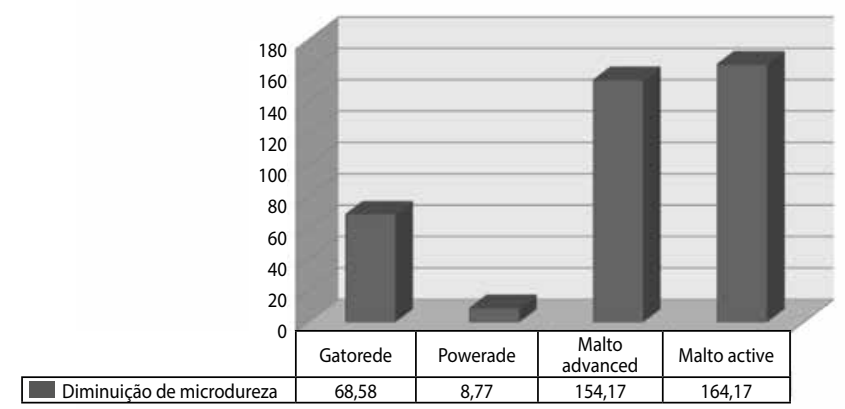

Figure 3. Decrease in microhardness of enamel exposed to the drinks. 


\section{DISCUSSION}

Gatorade demonstrated a decrease in microhardness (68.58) that was similar to that presented by Xavier et al. (2010) (64.78), who also evaluated lime-flavored Gatorade at room temperature. ${ }^{3}$ Ehlen et al. (2008) associated dental erosion with the enamel and root surface exposure to Gatorade, measuring the depth of the lesions caused on the surfaces, and identified that the lesions on the root surface exposed to Gatorade were superior to all the other drinks tested. ${ }^{22}$

This study used the drinks at room temperature, according to Xavier et al. (2010), who verified that temperature had no influence on the results. ${ }^{3}$ However, Cavalcanti et al. (2010), who measured the $\mathrm{pH}$ levels of nine isotonic sports drinks at room temperature and at $9{ }^{\circ} \mathrm{C}$, concluded that temperature influences the erosive potential of the tested drinks, recommending their intake at a cool temperature in order to reduce the deleterious effects on the teeth. ${ }^{1}$ Similarly, Corso et al. (2006) also concluded that temperature influences the erosive potential of the tested drinks. ${ }^{20}$ Thus, it can be observed that the literature has no definite consensus regarding the temperature and erosive capacity of drinks.

Cochrane et al. (2012) tested the erosive potential of ten sports drinks, including Gatorade and Powerade, and concluded that all the drinks tested had erosive potential. 5 Similarly, our study revealed the demineralization of enamels exposed to Gatorade. However, in contrast, Powerade did not present a statistically significant decrease in microhardness.

Studies examining the erosive potential of maltodextrin were not found in the literature. Nonetheless, in this study, Malto Advanced and Malto Active demonstrated statistically significant results in the microhardness of the enamel, with these differences being higher compared to those presented by isotonic sports drinks. We suggest that more studies should evaluate maltodextrin's erosive potential.

A possible explanation for the reduction in microhardness is the $\mathrm{pH}$ level of the tested substances, which is considered to be potentially erosive to dental surfaces because it is below the critical value for hydroxyapatite crystal dissolution., 18,20

The beverages selected in this study have a citric acid composition, which is an organic acid with erosive properties, that, in addition to provoking a drop in salivary $\mathrm{pH}$, thereby trigger the dissolution of dental enamel, act as a calcium-chelating substance, and increase demineralization of the enamel by elevating the local subsaturation conditions for this ion, resulting in demineralization even after neutralizing the $\mathrm{pH}$ level on the dental surface. ${ }^{16}$

Although Powerade has an acidic pH of 2.6 (according to the manufacturer) and citric acid as its composition, a probable explanation as to why this isotonic sports beverage does not cause a significant reduction in the hardness of the enamel is the presence of calcium (calcium chloride) in its composition, which is not present in other beverages. Studies are currently being conducted to improve these drinks, with the focus on improving their properties by reducing the quantity of sugars or by adding calcium or phosphate, in order to provide an increase in the degree of hydroxyapatite saturation. ${ }^{3}$

Studies performed by Attin et al. (2003) and Hughes et al. (2000) compared the wear caused by citric acid and a mixture of citric acid with calcium on dental surfaces, concluding that the addition of calcium to citric acid caused a smaller loss in hardness. Thus, the authors recommended adding calcium to drinks with erosive potential in order to decrease dental erosion caused by their consumption, which our results corroborated. ${ }^{23,24}$

Moreover, Amaral et al. (2010) compared the microhardness of the enamel exposed to the clarifying agent 35\% hydrogen peroxide with or without calcium in its composition. A significant $5.47 \%$ increase was observed in the microhardness of the surface exposed to the hydrogen peroxide with calcium, and a $2.59 \%$ reduction was noted in the microhardness of the surface exposed to hydrogen peroxide without calcium, which is not considered to be significant. The authors concluded that the presence of calcium in the clarifying gel positively influences the microhardness of human dental enamel. ${ }^{25}$

It is worth noting that in laboratory experiments, dental enamel is exposed to the action of beverages for a definite period of time, without considering the quantity consumed in real conditions, the time and movements executed during deglutition, the oral conditions and salivary composition, and their remineralization potential., 18,20

Sports drinks should not be consumed indiscriminately. They should be consumed as recommended and in moderation because these beverages generally have the capacity the cause dental erosion. Initially, dental erosion may be imperceptible; however, long-term intake and frequency of consumption may cause greater consequences, such as sensitivity, loss of dental structure, and dentin exposure.

Dental surgeons must stay alert to clinically identifying the signs of erosion in order to make an early diagnosis. At the same time, the etiology of erosion in their patient should be discovered in order to inform them of the risks and advise them on preventive methods and moderate consumption of acidic foods and beverages that may be causing the erosion. Physically active people, professional athletes, and their trainers who consume these sports drinks should also regularly know about the oral hygiene risks that their consumption may be causing to dental surfaces.

Adopting methods to prevent and control erosion, such as fluoride mouthwash and fluoridated dentifrices, increase the enamel's resistance to dissolution provoked by acids through mineral recovery. The use of oral protectors or straws to minimize dental contact with erosive agents and consumption of drinks at low temperatures may decrease erosive potential. Tooth brushing immediately after the dental surface's exposure to acidic drinks must be avoided in order to enable $\mathrm{pH}$ neutralization of the oral environment and not cause more considerable losses through the mechanical action of brushing. ${ }^{12,14}$ According to results found in this study, sports drinks with calcium in their composition may be indicated for consumption.

\section{CONCLUSION}

The microhardness of the human enamel submersed in the isotonic sports drink, i.e., Gatorade, and in maltodextrin, i.e., Advanced Series and Malto Active, significantly decreased, whereas it did not present a significant decrease in the isotonic sports beverage, Powerade.

All authors declare no potential conflict of interest related to this article.

AUTHORS' CONTRIBUTIONS: Each author made significant individual contributions to this manuscript. DMD (0000-0003-0058-4117)* planning of the research, literature review, conducted the experimental period, preparation of the results chart and table, discussion of results and writing of the work; GAA (0000-0001-9580-6282)* planning of the research, directed the experimental period, statistical analysis, participated in the discussion, writing of the work and critical review of the intellectual content; $\mathrm{HAS}(0000-0002-7116-2301)^{*}$ participated in the experimental period, preparation of the results chart and table and discussion of results; LHS (0000-0001-6424-6729)* responsible for the microhardness test, trained and supervised the researcher who took the test measurements, prepared a results report and data table; DRK (0000-0002-1258-9321)* took the microhardness test measurements, preparing a results report and data table. *ORCID (Open Researcher and Contributor ID). 


\section{REFERENCES}

1. Cavalcanti AL, Xavier AFC, Souto RQ, Oliveira MC, Santos JA, Vieira FF. Avaliação in vitro do potencial erosivo de bebidas isotônicas. Rev Bras Med Esporte. 2010;16(6):455-8.

2. Nóbrega DF, Valença AMG, Santiago BM, Claudino LV, Lima AL, Vieira TI, et al. Propriedades físico-químicas da dieta líquida gaseificada: um estudo in vitro. Rev Odontol UNESP. 2010;39(2):69-74.

3. Xavier AFC, Cavalcanti AL, Montenegro RV, Melo JBCA. Avaliação in vitro da microdureza do esmalte dentário após exposição a bebidas isotônicas. Pesqui Bras Odontop Clin Integr. 2010;10(2):145-50.

4. Ferreira CFS, Belli F, Raggio WCS, Navarro F. Uso de suplementos nutricionais por adolescentes em academias do interior e de São Paulo capital. Rev Bras Nutr Esporte. 2008;2(10):154-65.

5. Cochrane $\mathrm{NJ}$, Yuan Y, Walker GD, Shen P, Chang CH, Reynolds C, et al. Erosive potential of sports beverages Aust Dent J. 2012;57(2):359-64

6. Brasil. Portaria n. 222, de 24 de março de 1998. Agência Nacional de Vigilância Sanitária - ANVISA. Ministério da Saúde. 1998.

7. Sapata KB, Fayh APT, Oliveira AR. Efeito do consumo prévio de carboidratos sobre a resposta glicêmica e desempenho. Rev Bras Med Esporte. 2006;12(4):170-4.

8. Salas MMS, Chisini LA, Ferreira FV, Demarco FF. Erosão dentária na dentição permanente: epidemiologia e diagnostico. RFO. 2015;20(1):126-34.

9. Santos FG, Aguiar YPC, Cavalcanti AL. Caracterização metodológica dos estudos in situ sobre erosão dentária: uma abordagem atual. Rev Bras Ciên Saúde. 2013;17(1):105-12.

10. Ferrazzano GF, Coda M, Cantile T, Sangianantoni G, Ingenito A. SEM investigation on casein phosphopeptides capability in constrasting cola drinks enamel erosion: an in vitro preliminary study. Eur $\rfloor$ Paediatr Dent. 2012;13(4):285-8.

11. Olaya EIC, Vela MAM. Microdureza superficial del esmalte dentario ante El efecto erosivo de tres bebidas gasificadas no alcohólicas. Estudo in vitro. Kiru. 2011; 8(2):88-96

12. Catelan A, Guedes APA, Santos PH. Erosão dental e suas implicações sobre a saúde bucal. RFO 2010;15(1):83-6.

13. Schlueter N, Hara A, Shellis RP, Ganss C. Methods for the measurement and characterization of erosion in enamel and dentine. Caries Res. 2011:45(Suppl 1):13-23.
14. Messias DCF, Serra MC, Turssi CP. Estratégias para prevenção e controle da erosão dental. Rev Gaúcha Odontol. 2011:59:7-13.

15. Vasconcelos FN, Vieira SCM, Colares V. Erosão dental: diagnóstico, prevenção e tratamento no âmbito da saúde bucal. Rev Bras Ciên Saúde. 2010;14(1):59-64.

16. Ramos BLM, Farias MMAG, Silveira EG. Mensuração do potencial erosivo de diferentes tipos de bebidas industrializadas sabor uva. Salusvita. 2015;34(1):45-55

17. Rebelato R, Alencar CRB, Magalhães AC, Honório HM, Rios D. Comparação in vitro do efeito erosivo de refrigerantes zero ou light em relação à versão regular. Pesq Bras Odontoped Clin Integr. 2012;12(2):203-7.

18. Assis CD, Barin CS, Ellensohn RM. Estudo do potencial de erosão dentária de bebidas ácidas. UNOPAR Cient Ciênc Biol Saúde. 2011;13(1):11-5.

19. Xavier AFC, Paiva MPN, Brito RT, Santos TKG, Melo JBCA, Cavalcanti AL. Efeito dos sucos de frutas industrializados na microdureza do esmalte dental permanente. Rev Bras Ciên Saúde. 2011;15(2):137-42.

20. Corso S, Padilha DMP, Corso AC, Hugo FN. Avaliação do potencial erosivo de sucos de fruta artificiais em pó, refrigerantes, isotônicos e chás enlatados disponíveis comercialmente no Brasil. Rev Fac Odonto UPF. 2006;11(1):45-50

21. Medeiros JMF, Ferreira GS, Habitante SM, Dollinger CFAV, Forghieri AA, Haddad MS Fo. Analise da dureza Vickes da superfície de dentes artificiais em resina poliéster. Rev odontol Univ Cid São Paulo. 2014;26(1):23-37.

22. Ehlen LA, Marshall TA, Qian F, Wefel JS, Warren JJ. Acidic beverages increase the risk of in vitro tooth erosion. Nutr Res. 2008;28(5):299-303.

23. Attin T, Meyer K, Hellwig E, Buchalla W, Lennon AM. Effect of mineral supplements to citric acid on enamel erosion. Arch Oral Biol. 2003,48(11):753-9.

24. Hughes JA, West NX, Parker DM, van den Braak MH, Addy M. Effects of $\mathrm{pH}$ and concentration of citric, malic and lactic acids on enamel, in vitro. J Dent. 2000; 28(2):147-52.

25. Amaral PG, Sales GCF, Santos RL, Magalhães DBL, Gusmão ES. Influência da presença do cálcio em agentes clareadores e sua relação com a microdureza do esmalte dental humana. Rev Bras Ciên Saúde. 2010;14(2):37-44 